\title{
Faktor Pendidikan Anggota dalam Meningkatkan Partisipasi Anggota Koperasi Sebagai Pemilik Dan Pelanggan
}

\author{
Ujang Gunawan \\ Dewan Koperasi Indonesia \\ ug_inhe@yahoo.com
}

\begin{abstract}
ABSTRAK
Hasil uji penelitian baik secara parsial maupun simultan membuktikan bahwa faktor pendidikan dan pelatihan anggota yang terdiri dari materi diklat, metode dan media, pelatih dan peserta memiliki hubungan dan berpengaruh positif terhadap partisipasi anggota sebagai pemilik dan pelanggan pada Koperasi Kojamas, dimana materi diklat merupakan faktor determinan dibandingkan dengan faktor lainnya. Sehingga semakin baik materi diklat yang diajarkan, semakin efektif metode dan media yang digunakan, semakin baik kompetensi yang dimiliki pelatih dan semakin aktif peserta terlibat dalam proses belajar mengajar, maka semakin paham anggota akan hak dan kewajibannya serta manfaat atau benefit berkoperasi, maka semakin tinggi tingkat partisipasi anggota.
\end{abstract}

Kata Kunci : pendidikan anggota, partisipasi anggota, faktor determinan.

\section{ABSTRACT}

The result of partial test and simultaneously are indicating that there was positive and significant effect of the learning material, method and media, trainers, against the members of participant on Koperasi Kojamas and learning material is determinant factor than others. In other word, the better learning material, more effective of the method and media which being used, the more competence skill which trainers has and participant in the class, more the highest of the participation members should be.

Key words : members education, participation, determinant factor.

\section{LATAR BELAKANG}

Sejarah panjang keberadaan koperasi sebagai gerakan ekonomi rakyat maupun sebagai badan usaha sudah dimulai sejak penghujung tahun $1896 \mathrm{di}$ pelopori oleh seorang Patih Purwokerto yaitu R. Aria Wiriaatmaja dengan mendirikan badan usaha yang mengadopsi pola Koperasi Raiffeisen dengan tujuan untuk membantu ekonomi para priyayi masa itu agar terbebas dari cengkeraman rentenir. Dalam perjalanan selanjutnya hingga saat ini keberadaan koperasi di Indonesia dirasakan cenderung jalan di tempat sehingga belum mampu menyaingi pelaku ekonomi lainnya seperti BUMN dan BUMS, meskipun jumlah koperasi terus bertambah hingga mencapai 212.135 unit koperasi. Ironisnya dari jumlah koperasi tersebut hanya sekitar 27 persen saja yang mampu melaksanakan kewajiban Rapat Anggota.
Gambaran di atas membuktikan betapa lemahnya koperasi di Indonesia menjalankan nilai-nilai dan prinsip-prinsip koperasi sehingga berdampak luas terhadap kemajuan koperasi. Hal ini disebabkan karena minimnya pengetahuan anggota tentang fungsi dan peran anggota yang bersifat ganda yaitu sebagai pemilik dan pelanggan, oleh karena prinsip ganda itu tidak dapat dipahami dan dijalankan maka kemudian timbul permasalahan-permasalahan internal dan permasalahan yang menyangkut pihak eksternal seperti kasus koperasi yang terjadi selama ini yang mengorbankan anggotanya.

Pemahaman tentang nilai-nilai dan prinsip-prinsip koperasi tidak serta merta timbul atau tumbuh begitu saja dengan sendirinya, akan tetapi perlu diberikan melalui pendidikan dan pelatihan. Oleh karena itu, inilah pentingnya pendidikan dan pelatihan (diklat) bagi anggota karena melalui diklat 
akan dapat membangkitkan keterampilan (skill) dan sikap (attitude) sehingga setelah diberikan pengetahuan, maka timbul pemahaman, kemudian muncul kesadaran (awareness/attention) dan minat serta rasa keingintahuan (interest and search), kemudian pada gilirannya bersedia untuk berpartisipasi (action, share).

Pendidikan dan pelatihan anggota koperasi yang baik adalah yang dapat membuat anggota paham dan dapat diaplikasikan dalam kehidupan berkoperasi terutama menyangkut tentang nilai menolong diri sendiri (selfhelp), percaya pada kemampuan sendiri (self realibility) dan tanggungjawab (self responsibility). Lembaga Pendidikan Perkoperasian (Lapenkop) banyak melaksanakan pendidikan dan pelatihan bagi anggota koperasi di Kota Bandung, sebut saja salah satu koperasi yang seluruh anggotanya telah dilatih yaitu Koperasi Jama'ah Masjid Al-Muttaqien (Kojamas) yang menunjukan fenomena positif, yakni :

Tabel. 1. Jumlah Anggota, Kehadirannya di RAT, Posisi Simpanan dan Pinjaman.

\begin{tabular}{lcccccc}
\hline Tahun & $\begin{array}{c}\text { Jumlah } \\
\text { anggota } \\
\text { (orang) }\end{array}$ & $\begin{array}{c}\text { Tingkat } \\
\text { kehadiran } \\
\text { di RAT }\end{array}$ & $\begin{array}{c}\text { Simpanan } \\
\text { Pokok } \\
\text { (Rp.juta) }\end{array}$ & $\begin{array}{c}\text { Simpanan } \\
\text { Wajib } \\
\text { (Rp.juta) }\end{array}$ & $\begin{array}{c}\text { Simpanan } \\
\text { Sukarela } \\
\text { (Rp.juta) }\end{array}$ & $\begin{array}{c}\text { Volume } \\
\text { Pinjaman } \\
\text { (Rp.juta) }\end{array}$ \\
\hline 2012 & 251 & $82 \%$ & 12.5 & 123 & 360.3 & 1.067 \\
\hline 2013 & 297 & $79 \%$ & 14.8 & 174 & 520.5 & 1.735 \\
\hline 2014 & 387 & $78 \%$ & 19.3 & 258 & 806.1 & 2.452 \\
\hline 2015 & 424 & $83 \%$ & 21.2 & 351 & 1.013 & 3.145 \\
\hline 2016 & 471 & $81 \%$ & 23.5 & 472 & 1.243 & 3.273 \\
\hline
\end{tabular}

Sumber : Laporan RAT

\section{Perkoperasian}

Koperasi, ditinjau dari akar katanya, berasal dari kata co artinya bersama dan operation berarti bekerja (Syamsudin Mahmud:1996:109), sehingga koperasi berarti bekerjasama di antara dua pihak atau lebih dalam aspek ekonomi.

Aspek ekonomis pada koperasi senantiasa dikaitkan dengan upaya-upaya kelompok yang secara bersama-sama menjalankan usaha agar dapat memberikan keuntungan ekonomis bagi anggotanya. Alat untuk mencapai tujuan tersebut menurut Ramudi Ariffin (2013:144) adalah melalui Perusahaan Koperasi. Demikian pula pendapat Ibnoe Soedjono tentang arti koperasi yaitu koperasi adalah perkumpulan otonom dari orang-orang yang bersatu secara sukarela untuk memenuhi kebutuhan-kebutuhan dan aspirasi ekonomi, sosial dan budaya bersama melalui perusahaan yang dimiliki bersama dan dikendalikan secara demokratis (Ibnoe Soedjono:2013:8). Untuk itu maka peran koperasi sebagai badan usaha ekonomis harus mampu mewujudkan cita-citanya serta tetap memegang teguh prinsip koperasi, sebab manakala koperasi hanya dikelola sebagai badan usaha seperti usaha swasta, maka bisa jadi koperasi sama halnya dengan perusahaan kapitalistik yang tidak terikat dengan mensejahterakan anggotanya dan tidak memberikan manfaat langsung bagi anggotanya, namun bisa juga sebaliknya, jika koperasi hanya memegang teguh prinsip dan jatidiri koperasi tetapi kinerjanya rendah hal ini pun tidak akan memberikan kemanfaatan bagi anggota.

\section{Jatidiri Koperasi}

Jatidiri Koperasi atau Cooperative Identity Statement (CIS) merupakan ciri khas atau karakteristik koperasi, yang membedakan koperasi dengan korporasi atau organisasi lainnya di manapun yaitu sebagai pemilik dan pelanggan (dual identity). Sebagai pemilik, anggota bertanggungjawab menjaga, membina dan mengembangkan koperasinya. Dan sebagai pelanggan atau pengguna, anggota wajib bertanggungjawab memanfaatkan layanan yang diselenggarakan koperasi. Peran anggota sebagai pemilik koperasi diwujudkan dalam bentuk :

1) Memprakarsai dan mendirikan koperasi;

2) Memodali dan membiayai usaha koperasi;

3) Melakukan pengelolaan koperasi

4) Mengawasi jalannya usaha koperasi.

Adapun sebagai pengguna atau pelanggan, setiap anggota berhak dan wajib memanfaatkan berbagai bentuk pelayanan yang diselenggarakan koperasi, seperti misalnya : 
1) Meminjam dari koperasi dan mengembalikan pinjaman koperasi;

2) Berbelanja bersama di toko koperasi;

3) Menjual bersama-sama melalui koperasi;

\section{Pendidikan dan Pelatihan Anggota}

Bung Hatta mengatakan bahwa pendidikan harus dimulai dari anak-anak untuk membentuk karakter. Hal tersebut sejalan dengan pendapat dari Langeveld dalam Burhanuddin Salam (2002:4) seorang ahli pedagogik dari Belanda mengatakan bahwa pendidikan adalah suatu bimbingan, di mana bimbingan itu adalah sebagai suatu proses.

Pendidikan merupakan modal bagi koperasinya untuk mendidik anggota agar memahami dan menumbuhkan kesadaran untuk berpartisipasi secara aktif dalam setiap kegiatan koperasi. Pendidikan Anggota telah menjadi bagian yang melekat dalam koperasi, dan bahkan menjadi salah satu dari prinsip koperasi yang dirumuskan di Rochdale tahun 1844. Pendapat dari U. Sanurdin Natadirana yang disampaikan dalam buku "20 Pokok Pemikiran Tentang Pembangunan Koperasi (2002:12), Editor Rusidi dan Suratman", bahwa PR Dubashi menyatakan, secara alami manusia dikendalikan oleh naluri menolong diri sendiri (self-help), naluri saling membantu (mutual help), naluri demokrasi, hasrat yang bebas untuk menekan nalurinya, akan tetapi menurutnya bahwa dalam kenyataannya sifat atau naluri tersebut bukanlah bersifat alami, melainkan dibentuk lewat pendidikan.

Pentingnya pendidikan bagi anggota koperasi, disampaikan juga oleh Thoby Mutis (2004:95) bahwa pendidikan bagi anggota dan calon anggota merupakan kebutuhan yang mendasar. Andaikata para anggota memperoleh pendidikan ini, mereka akan mampu berperan secara pantas dalam aneka kegiatan atau peristiwa di koperasinya dan dapat melaksanakan pertanggungjawabannya, kewajiban, dan rasa persaudaraan secara teratur. Kegiatan pendidikan, menurut La Sulo \& Tirtarahardja (2013:163) dapat dilaksanakan di tiga lingkungan utama yakni dalam lingkungan keluarga, sekolah dan masyarakat.

Pendidikan Anggota yang diselenggarakan Lapenkop adalah dalam bentuk Diklat yang bersifat jangka pendek yang berangkat dari pemahaman bahwa kedudukan anggota dalam koperasi memiliki posisi yang strategis dan penting, oleh karenanya sangat penting bagi setiap anggota kompeten dalam hal:
1) Memahami dengan jelas pengertian, nilai-nilai dan prinsip koperasi;

2) Terampil dalam menyikapi kasus-kasus dalam kehidupan nyata berkoperasi;

3) Terampil dan percaya diri berbicara dalam Rapat Anggota;

4) Memahami manfaat dan pentingnya peran serta anggota dalam koperasi;

5) Memahami dengan jelas hak dan kewajiban sebagai anggota;

6) Mengenal struktur, fungsi dan tugas setiap perangkat organisasi koperasi;

7) Memahami hakekat usaha koperasi;

8) Menemukan kiat-kiat berwirausaha dengan Baik;

9) Terampil menghitung harga pokok produksi dan harga penjualan;

10) Memahami cara-cara menganalisa masalah dan potensi usaha;

11)Menemukan cara untuk pemecahan masalah usahanya;

12)Terampil dalam menghitung SHU bagian anggota;

13)Terampil dalam membaca laporan keuangan Koperasi.

Pemahaman dan keterampilan tersebut dikemas ke dalam 4 faktor pendidikan yaitu : materi diklat, metode dan media, pelatih dan peserta diklat.

\section{Materi Pendidikan dan Pelatihan (Diklat)}

Materi merupakan bahan yang telah dipilih dan disesuaikan dengan tujuan pendidikan dan kebutuhan peserta didik. Oleh karenanya materi yang merupakan bahan ajar harus dibuat secara komprehensif yang memuat jelas lingkup kandungannya agar sesuai dengan tujuan pendidikan serta kelompok sasaran sebagai peserta. Materi pendidikan harus dapat diimplementasikan dan menjawab permasalahan yang dihadapi di lapangan. Menurut Fuad Ihsan (2002:9) adalah segala sesuatu yang diberikan langsung kepada peserta didik dalam rangka mencapai tujuan pendidikan. Hal ini didukung pendapat La Sulo \& Tirtarahardja (2013:56) bahwa materi telah diramu dalam kurikulum yang akan disajikan sebagai sarana pencapaian tujuan.

\section{Metode dan Media}

Metode adalah cara untuk mendekatkan materi dengan peserta diklat dengan metode pendidikan orang dewasa (POD) atau androgogi, metode ini menggunakan pendekatan partisipatif, di mana peserta didik dan pendidik (pelatih) berpartisipasi 
aktif. Metode POD, tidak hanya pendengaran (telinga) dan penglihatan (mata) yang digunakan akan tetapi juga termasuk gerak tubuh (body). Beberapa teknik belajar yang biasa diterapkan pada saat diklat adalah : a) Metode Simulasi, b) Metode Curah pendapat, c) Metode Diskusi kelompok, d) Metode Diskusi Media, e) Bermain peran (game) dan f). Studi kasus dan penugasan.

Media adalah bahan peragaan atau rujukan bagi Pelatih dalam melaksanakan tugasnya. Media dipergunakan sebagai alat peraga, sehingga dapat dengan mudah diamati dan dipahami. Penggunaan alat peraga atau belajar dengan melibatkan benda-benda, menurut Made Pidarta (2007:5) merupakan teori mendidik didaktik, yang lebih dikenal saat ini dengan istilah Proses Belajar Mengajar (PBM).

\section{Pelatih}

Pelatih menurut La Sulo \& Tirtarahardja (2013:54) adalah orang yang bertanggung jawab terhadap pelaksanaan pendidikan dengan sasaran peserta didik. Seorang Pelatih harus memiliki kemampuan dalam penguasaan materi dan kemampuan mengajar (teaching skill), sehingga pemahaman dari pendidik terhadap potensi dan sifat dasar manusia adalah sangat penting untuk tercapainya tujuan pendidikan. Syarat pelatih yang baik menurut Hasibuan (2014:75), selain memiliki kemampuan untuk mendidik (Teaching skills) adalah juga harus memiliki kompetensi teknis (Technical compentent), kecakapan teoritis dan tangkas dalam mengambil suatu keputusan. Dengan demikian, maka seorang Pelatih dituntut untuk mengintegrasikan pengetahuan, keterampilan, sikap dan nilai-nilai positip dalam melaksanakan tugas dan perannya sebagai seorang Pelatih.

\section{Peserta Diklat}

Peserta adalah pribadi yang otonom sebagai pelaku dalam kegiatan pendidikan dan pelatihan yang memiliki potensi dan kemampuan untuk mandiri, dimana dalam proses perkembangannya membutuhkan bimbingan untuk berkembang. Selain itu peserta merupakan pelaku. Pendapat Umar Tirtarahardja dan La Sulo (2013:52) peserta didik adalah merupakan subjek didik.

Dalam metode Lapenkop peserta bukan objek belajar akan tetapi warga belajar, peserta dan pendidik berperan setara atau sebaliknya, sehingga dengan demikian timbul komunikasi multi arah.
Dengan cara ini diharapkan akan dapat membangkitkan partisipasi peserta untuk berperan aktif dalam proses pelaksanaan pendidikan dan pelatihan.

\section{Partisipasi Anggota}

Secara harfiah partisipasi diambil dari bahasa asing participation, yang artinya mengikut sertakan pihak lain dalam mencapai tujuan (Hendar dan Kusnadi, 2005:91). Kesuksesan koperasi adalah sangat bergantung kepada partisipasi anggota, karena partisipasi anggota adalah merupakan basis kekuatan koperasi.

Keterlibatan dan keikutsertaan anggota atau yang disebut dengan "partisipasi anggota" dalam koperasi memiliki pengaruh terhadap keunggulan kinerja koperasi. Partisipasi anggota dan kualitas usaha memiliki hubungan saling mempengaruhi, dimana eksistensi koperasi tergantung pada dua hal itu secara sinergi (Rully Indrawan,2004:57).

Menurut Hanel, dalam Rully Indrawan (2004:58) bahwa partisipasi anggota yang diwujudkan dalam partisipasi permodalan, manajemen dan transaksi usaha dapat berkembang selaras dengan berkembangnya proses organisasi yang dijalankan oleh manajemen koperasi. Pendapat dari Hanel tersebut bermakna bahwa partisipasi anggota dapat dibuktikan dari adanya kesadaran anggota untuk bersedia mencurahkan pikiran, tenaga dan waktunya dalam menjalankan organisasi koperasi, berkontribusi menyimpan dananya di koperasi serta memanfaatkan jasa atau layanan yang disediakan oleh koperasi.

Partisipasi anggota merupakan unsur utama dalam memacu kegiatan dan untuk mempertahankan ikatan pemersatu di dalam koperasi (Thoby Mutis, 2004:93). Tanpa partisipasi anggota, maka kemungkinan atas rendah atau menurunnya efisiensi dan efektivitas anggota dalam rangka mencapai kinerja koperasi akan lebih besar (Röpke (2000:45).

Partisipasi anggota diukur dari kesediaan anggota itu memikul kewajiban dan menjalankan hak keanggotaan secara bertanggung jawab. Jika sebagian besar anggota koperasi sudah menunaikan kewajiban dan melaksanakan hak secara bertanggung jawab, maka partisipasi anggota koperasi yang bersangkutan sudah dinilai baik. Menurut Anaroga dan Nanik (2003:111), jika ternyata hanya sedikit yang memikul kewajiban dan menjalankan haknya, maka partisipasi angggota koperasi tersebut dikatakan buruk atau rendah. 
Berdasarkan uraian di atas, maka dapat disimpulkan bahwa antara anggota dan koperasi merupakan dua elemen yang saling menopang dan memiliki keterkaitan antara satu dan lainnya, anggota adalah asset dan sebagai Sumber Daya Manusia Koperasi (SDMK) yang dibutuhkan partisipasinya, dimana kehandalan dari anggota sebagai sumber daya manusia akan membawa pengaruh dan merupakan keuntungan bagi koperasi. Pendapat dari Rusdiana (2014:308) bahwa kemampuan sumber daya manusia adalah merupakan competitive advantage.

\section{Partisipasi Anggota Sebagai Pemilik}

Dalam kedudukannya sebagai pemilik, anggota terikat dengan kewajiban-kewajiban yang harus dipenuhi, sebagai pemilik anggota memiliki kewajiban menentukan kebijakan dan arah organisasi. Keperilakuan anggota sebagai pemilik lebih kompleks daripada sebagai pelanggan, sebagai pemilik anggota dibebani hak dan kewajiban yang berat. Herman Soewardi (1995:49).

Sebagai pemilik, anggotalah yang menentukan maju dan mundurnya koperasi, karena keterlibatannya sebagai pemilik dimulai dari rencana program yang ditetapkan dalam forum tertinggi yaitu Rapat Anggota. Sebagai pemilik, maka anggota harus mendukung program dan rencana kegiatan koperasi

Keterlibatan para anggota secara aktif pada forum tertinggi koperasi adalah mencerminkan kualitas rapat dan sekaligus juga mencerminkan kualitas anggota sebagai sumberdaya manusia yang berkompeten.

\section{Partisipasi Anggota Sebagai Pelanggan :}

Dalam kedudukannya sebagai pelanggan, para anggota bertanggung jawab terhadap suksesnya program-program yang ditetapkan dalam rapat anggota, para anggota wajib memanfaatkan berbagai potensi yang disediakan oleh koperasi dalam menunjang kepentingannya.

Hanel (2005:78), menyatakan bahwa partisipasi anggota sebagai pelanggan atau pemakai, yaitu dicerminkan oleh para anggota memanfaatkan berbagai potensi yang disediakan oleh koperasi dalam menunjang kepentingannya.

Tanggung jawab tersebut tidak hanya sebatas memanfaatkannya saja, akan tetapi termasuk memodali dan membiayainya sebagai wujud dari adanya partisipasi finansial. Kewajiban para anggota untuk memanfaatkan pelayanan koperasi tersebut pada dasarnya adalah merupakan amanah dari para anggota koperasi sendiri, sehingga wajib untuk dilaksanakan oleh para anggota.

Partisipasi anggota dalam pelayanan yang diberikan oleh koperasi akan terwujud jika terjalin kesesuaian di antara anggota, dan program yang ditawarkan koperasi, sebagaimana digambarkan oleh Röpke melalui model kesesuaian partisipasi (fit models participation), yakni : a). kesesuaian antara kebutuhan anggota dengan pelayanan dan sumber-sumber daya yang disediakan koperasi sebagai output dari program, b). kesesuaian antara apa yang dibutuhkan anggota dengan manajemen koperasi, c). kesesuaian antara syarat-sayarat kepentingan program dan kemampuan manajemen koperasi.

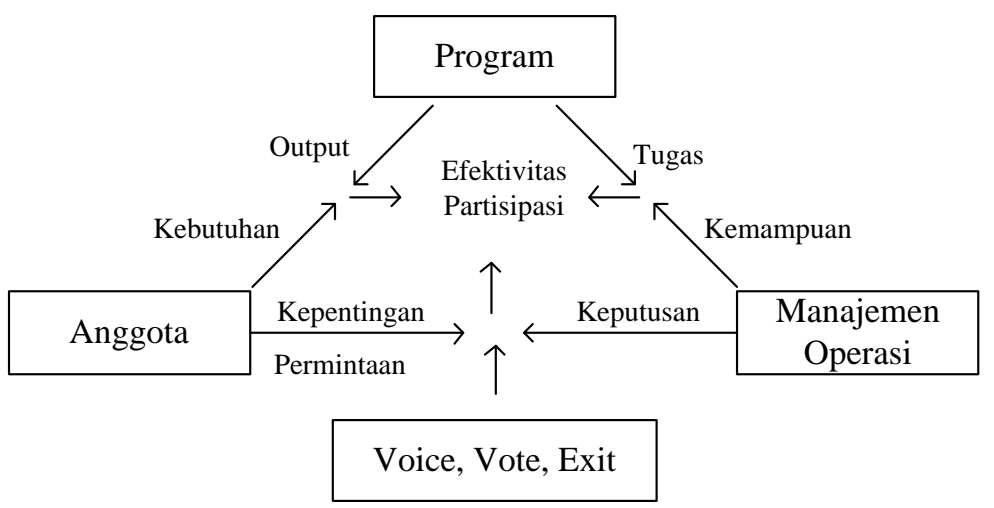

Gambar 1. Model Kesesuaian Partisipasi.

Sumber : Röpke (2000:62)

\section{METODE PENELITIAN}

Jenis penelitian ini adalah survai menggunakan metode kuantitatif dengan tipe penelitian asosiatif kausal, yaitu melihat hubungan yang bersifat sebab akibat antara variabel bebas (independen) yang terdiri dari materi diklat, metode dan media, pelatih, 
peserta terhadap variabel terikat (dependent) yaitu partisipasi anggota sebagai pemilik dan pelanggan.

Populasi dalam penelitian ini adalah keseluruhan anggota koperasi sebanyak 471 orang yang ditetapkan sesuai dengan syarat-syarat tertentu untuk menjawab masalah penelitian. Teknik penarikan sampel secara acak sederhana (Simple Random Sampling), menggunakan rumus Slovin sehingga diperoleh sampel sebanyak 82 orang anggota koperasi.

Pengujian validitas instrumen dilakukan dengan menghitung nilai korelasi antara data pada masing-masing pernyataan dengan skor total yang diperoleh dengan menggunakan rumus Rank
Spearman. Adapun uji reliabilitas dengan pengujian statistik cronbach alpha $(\alpha)$.

Hipotesis penelitian secara parsial dengan uji t dan secara simultan dengan uji $F$, dengan merumuskan hipotesis statistik menolak Ho dan menerima Ha.

\section{HASIL DAN PEMBAHASAN}

Analisis Variabel Materi Diklat

Materi diklat ini mengandung bahan ajar yang diberikan kepada peserta diklat meliputi bahasan tentang : (a). Memahami koperasi yang ideal, (b). Organisasi koperasi, (c). Rapat anggota, (d). Peran serta anggota, (e). SHU, (f). Membaca laporan keuangan koperasi.

Tabel. 2. Hasil Penilaian Responden Tentang Materi Diklat

\begin{tabular}{|c|c|c|c|c|}
\hline No & Isi materi yang membahas tentang & Total Skor & $\begin{array}{c}\text { Skor } \\
\text { Maksimum }\end{array}$ & Capaian \\
\hline 1. & Memahami Koperasi Ideal & 2029 & 2460 & $82 \%$ \\
\hline 2. & Organisasi Koperasi & 502 & 820 & $61 \%$ \\
\hline 3. & Rapat Anggota & 607 & 820 & $74 \%$ \\
\hline 4. & Peran Serta Anggota & 4555 & 5740 & $79 \%$ \\
\hline 5. & SHU & 345 & 410 & $84 \%$ \\
\hline \multirow{2}{*}{\multicolumn{2}{|c|}{$\begin{array}{r}\text { 6. Laporan Keuangan Koperasi } \\
\text { Variabel Materi Diklat }\end{array}$}} & 363 & 410 & $89 \%$ \\
\hline & & 8401 & 11070 & $76 \%$ \\
\hline
\end{tabular}

Berdasarkan hasil penilaian di atas, maka diperoleh kesimpulan bahwa sikap responden menyatakan setuju bahwa materi diklat telah memberikan pengaruh dan dampak terhadap pemahaman dan kesadaran anggota untuk

berpartisipasi dengan capaian $76 \%$ yang diperoleh dari perbandingan total skor responden 8401 terhadap total skor maksimum 11070. Dengan demikian dapat diketahui bahwa materi diklat yang diajarkan terbukti cukup efektif untuk meningkatkan pemahaman tentang perkoperasian dan kesadaran untuk berpartisipasi.

\section{Analisis Variabel Metode dan Media Diklat}

Variabel metode dan media diklat yang digunakan dalam diklat adalah (a) Metode Simulasi, (b). Metode Curah Pendapat, (c). Metode Diskusi Kelompok, (d). Metode Permainan (games) dan (d). Metode Studi Kasus (case study). Sedangkan media yang digunakan yaitu (a). Media Bahan Peragaan dan (b). Media Bahan Bacaan (handout).

Metode dan Media ini dianggap partisipatif karena mudah dilaksanakan dan sesuai dengan kelompok sasaran dan dianggap tepat untuk digunakan karena dalam prakteknya melibatkan gerak tubuh dan peran aktif dari peserta diklat. 
Tabel. 3

Hasil Penilaian Responden Tentang Metode dan Media

\begin{tabular}{llccc}
\hline No & Metode dan Media yang digunakan dalam diklat & $\begin{array}{c}\text { Total } \\
\text { Skor }\end{array}$ & $\begin{array}{c}\text { Skor } \\
\text { Maksimum }\end{array}$ & Capaian \\
\hline 1 & Metode Simulasi & 1744 & 2050 & $85 \%$ \\
\hline 2 & Metode Curah Pendapat & 835 & 1230 & $68 \%$ \\
\hline 3 & Metode Diskusi Kelompok & 419 & 820 & $51 \%$ \\
\hline 4 & Metode Permainan (Games) & 1057 & 1230 & $86 \%$ \\
\hline 5 & Metode Studi Kasus & 341 & 410 & $83 \%$ \\
\hline 6 & Media Bahan Pegangan & 164 & 410 & $40 \%$ \\
\hline 7 & Media Bahan Bacaan (hand out) & 397 & 820 & $48 \%$ \\
\hline & $\quad$ Variabel Metode dan Media Diklat & 4957 & 6970 & $71 \%$ \\
\hline
\end{tabular}

Hasil penilaian responden terhadap Metode dan Media yang dipergunakan dalam pelaksanaan diklat sebagaimana disajikan pada Tabel 3 di atas, membuktikan bahwa metode dan media yang digunakan cukup efektif dalam memberikan pemahaman terhadap meteri diklat, dengan capaian $71 \%$.

\section{Analisis Variabel Pelatih}

Kompetensi pelatih ditanggapi responden dengan baik, artinya responden setuju bahwa pelatih diklat memiliki kompetensi menguasai materi diklat dan mampu membangkitkan motivasi peserta diklat dengan capaian $66 \%$, sebagaimana hasil penelitian yang disajikan pada Tabel 4 di bawah ini.

Tabel. 4.

Hasil Penilaian Responden Terhadap Kompetensi Pelatih

\begin{tabular}{llccc}
\hline \multirow{2}{*}{ No } & Kompetensi Pelatih & Total Skor & $\begin{array}{c}\text { Skor } \\
\text { Maksimum }\end{array}$ & Capaian \\
\hline 1 & Mampu menguasai materi diklat & 772 & 1.230 & $63 \%$ \\
\hline 2 & $\begin{array}{l}\text { Mampu membangkitkan motivasi dan } \\
\text { penggunaan metode partisipatif }\end{array}$ & 1.172 & 1.640 & $71 \%$ \\
\hline 3 & Mempunyai keahlian sesuai materi diklat & 770 & 1.640 & $47 \%$ \\
\hline Variabel Kompetensi Pelatih & 2.714 & 4.100 & $66 \%$ \\
\hline
\end{tabular}

\section{Analisa Variabel Peserta Diklat}

Variabel ini terdiri dari indikator persyaratan pendidikan, pengetahuan, pengalaman dan usia yang merupakan indikator persyaratan menjadi peserta diklat. Berdasarkan hasil penelitian diketahui bahwa responden menyatakan setuju persyaratan untuk menjadi peserta diklat dengan memasukan pertimbangan aspek pendidikan, pengetahuan, pengalaman dan batas usia dengan capaian $62 \%$,

Tabel. 5.

Hasil Penilaian Responden Terhadap Peserta Diklat

\begin{tabular}{llccc}
\hline No & Persyaratan Peserta & Total Skor & Skor Maksimum & Capaian \\
\hline 1 & Pendidikan & 456 & 1230 & $37 \%$ \\
\hline 2 & Pengetahuan & 329 & 410 & $80 \%$ \\
\hline 3 & Pengalaman & 1019 & 1230 & $83 \%$ \\
\hline 4 & Usia & 483 & 820 & $59 \%$ \\
\hline \multicolumn{2}{r}{ Variabel Peserta } & 2287 & 3690 & $62 \%$ \\
\hline
\end{tabular}




\section{Analisa Variabel Partisipasi Anggota Sebagai Pemilik}

Hasil penelitian terhadap partisipasi anggota sebagai pemilik yang tercermin dari indikator : (a). membayar simpanan pokok, (b). membayar simpanan wajib, (c). membayar simpanan lainnya, (d). tingkat kehadiran pada RAT, (e). keaktifan dalam RAT, (f). melakukan pengawasan, (g). mendapatkan pembagian SHU adalah relatif tinggi yaitu mendapat skor 4113 dari skor maksimum 5330 sehingga capaiannya adalah $77 \%$. Dengan demikian maka pendidikan dan pelatihan anggota tersebut dinilai efektif dalam meningkatkan pemahaman tentang perkoperasian yang meliputi nilai-nilai dan prinsip-prinsip koperasi, sehingga dari pemahaman yang didapatkan, maka anggota dapat mengetahui manfaat atau benefitnya dan pada akhirnya timbul kesadaran anggota untuk berkontribusi atau berpartisipasi dalam memajukan usaha koperasi.

\section{Analisa Partisipasi Anggota Sebagai Pelanggan}

Anggota dalam kedudukannya sebagai pelanggan (user) tercermin dari tingkat keterlibatannya atau partisipasinya dalam koperasi. Untuk mengetahui atau mengukur partisipasi anggota sebagai pengguna jasa atau layanan koperasi, maka dapat diukur dari volume transaksi anggota serta frekuensi anggota bertransaksi di koperasi. Dari hasil penelitian diperoleh hasil bahwa tingkat partisipasi anggota sebagai pelanggan memiliki skor 1290 dan skor maksimum 1640, sehingga tingkat capaiannya adalah $79 \%$, artinya partisipasi anggota sebagai pelanggan telah dilakukan dengan baik.

Hasil penelitian terhadap partisipasi anggota sebagai pemilik dan pelanggan dapat disimpulkan tinggi dengan capaiannya $78 \%$ sebagaimana hasil penelitian berikut ini :

Tabel. 6. Hasil Penilaian Responden Terhadap Partisipasi Anggota Sebagai Pemilik Dan Pelanggan

\begin{tabular}{llccc}
\hline \multirow{2}{*}{ No } & \multicolumn{1}{c}{ Indikator } & Total Skor & $\begin{array}{c}\text { Skor } \\
\text { Maksimum }\end{array}$ & Capaian \\
\hline a) & Membayar Simpanan Pokok & 365 & 410 & $89 \%$ \\
\hline b) & Membayar Simpanan Wajib & 643 & 820 & $78 \%$ \\
\hline c) & Membayar Simpanan Lainnya & 602 & 820 & $73 \%$ \\
\hline d) & Kehadiran dalam RAT & 928 & 1230 & $75 \%$ \\
\hline e) & Keaktifan dalam RAT & 646 & 820 & $79 \%$ \\
\hline f) & Melakukan pengawasan & 310 & 410 & $76 \%$ \\
\hline g) & Mendapatkan pembagian SHU & 619 & 820 & $75 \%$ \\
\hline$\Sigma$. & Partisipasi anggota sebagai pemilik & 4113 & 5330 & $77 \%$ \\
\hline a) & Volume Transaksi & 639 & 820 & $78 \%$ \\
\hline b) & Frekuensi Transaksi & 651 & 820 & $79 \%$ \\
\hline$\Sigma$. & Partisipasi anggota sebagai pelanggan & 1290 & 1640 & $79 \%$ \\
\hline$\square$ Partisipasi anggota sebagai pemilik dan & 5403 & 6970 & $78 \%$ \\
\hline & pelanggan & & & \\
\hline
\end{tabular}

Penelitian ini, menggunakan uji asumsi klasik yang terdiri dari uji normalitas, uji heteroskedasitas, uji multikolinearitas, uji autokorelasi dan uji liniearitas, Hasil uji normalitas memenuhi asumsi nilai signifikansi karena terpenuhinya nilai $0.200>$ alpha 0.10. Adapun hasil uji heteroskedasitas berdasarkan Scatterplot di bawah ini, model regresi tidak mengandung heteroskedasitas. 


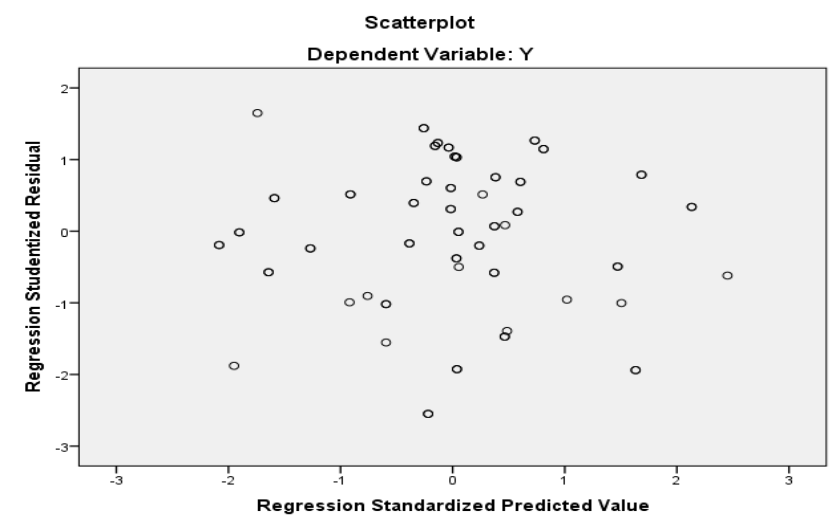

Gambar 3 Grafik Scatterplot

Hasil uji Multikolinearitas terbukti memiliki nilai VIF di bawah 10 dan memiliki angka tolerance di bawah 1 ( tolerance < 0.1 dan VIF <10). Sebagaimana Tabel 7 di bawah ini :

Tabel. 7. Hasil Uji Multikolinearitas

\begin{tabular}{|c|c|c|c|}
\hline & \multicolumn{3}{|c|}{ Coefficients $^{\mathrm{a}}$} \\
\hline & \multirow{2}{*}{ Model } & \multicolumn{2}{|c|}{ Collinearity Statistics } \\
\hline \multirow{5}{*}{1} & & Tolerance & VIF \\
\hline & X1 : Materi Diklat & .347 & 2.882 \\
\hline & $\begin{array}{l}\text { X2 : Metode dan } \\
\text { Media }\end{array}$ & .393 & 2.547 \\
\hline & X3 : Pelatih & .644 & 1.553 \\
\hline & X4 : Peserta & .606 & 1.649 \\
\hline
\end{tabular}

Hasil uji autokorelasi menggunakan uji Durbin-Watson (DW test) dengan kriteria pengambilan jika D - W sama dengan 2 diketahui bahwa tidak terjadi autokorelasi. Hal ini berdasarkan perhitungan nilai D - W untuk data ini adalah 1.876. Sedangkan nilai tabelnya du 1.743 , DI $=$ 1.534 dan $4-\mathrm{dL}=2.466$.

Tabel. 8. Hasil Uji Autokorelasi Model Summary ${ }^{\mathrm{b}}$

\begin{tabular}{lc}
\hline \multicolumn{1}{c}{ Model } & Durbin-Watson \\
\hline 1 & 1.876 \\
\hline $\begin{array}{l}\text { a. Predictors: (Constant), X4, X3, X2,X1 } \\
\text { b. Dependent Variable: } Y\end{array}$
\end{tabular}

Nilai signifikansi untuk uji linieritas adalah 0.0000 , artinya nilai signifikansi 0.000 lebih kecil dari alpha 0.1 yang digunakan, sehingga dengan demikian dapat disimpulkan bahwa terjadi hubungan linier antara variabel materi diklat, metode dan media, pelatih, peserta terhadap partisipasi anggota sebagaimana hasil olah data pada Tabel.9, Tabel 10, Tabel 11 dan Tabel 12.

Tabel. 9 Hasil Uji Linearitas Y $*$ X1

ANOVA Table

\begin{tabular}{|c|c|c|c|c|c|c|c|}
\hline & & & $\begin{array}{l}\text { Sum of } \\
\text { Squares }\end{array}$ & Df & $\begin{array}{l}\text { Mean } \\
\text { Square }\end{array}$ & $\mathrm{F}$ & Sig. \\
\hline \multirow[t]{5}{*}{$\mathrm{Y} * \mathrm{X} 1$} & Between & (Combined) & 7455.073 & 35 & 213.002 & 81.367 & .000 \\
\hline & Groups & Linearity & 3480.187 & 1 & 3480.187 & 1329.441 & .000 \\
\hline & & Deviation from Linearity & 3974.886 & 34 & 116.908 & 44.659 & .000 \\
\hline & \multicolumn{2}{|c|}{ Within Groups } & 28.796 & 11 & 2.618 & & \\
\hline & \multicolumn{2}{|l|}{ Total } & 7483.868 & 46 & & & \\
\hline
\end{tabular}

Tabel. 10 Hasil Uji Linearitas Y $*$ X2

\begin{tabular}{|c|c|c|c|c|c|c|c|}
\hline & & & $\begin{array}{l}\text { Sum of } \\
\text { Squares }\end{array}$ & Df & Mean Square & $\mathrm{F}$ & Sig. \\
\hline \multirow{5}{*}{$\mathrm{Y} * \mathrm{X} 2$} & \multirow{3}{*}{$\begin{array}{c}\text { Between } \\
\text { Groups }\end{array}$} & (Combined) & 4796.772 & 44 & 109.018 & 12.285 & .000 \\
\hline & & Linearity & 1952.248 & 1 & 1952.248 & 219.996 & .000 \\
\hline & & Deviation from Linearity & 2844.524 & 43 & 66.152 & 7.455 & .000 \\
\hline & \multicolumn{2}{|c|}{ Within Groups } & 328.339 & 37 & 8.874 & & \\
\hline & \multicolumn{2}{|r|}{ Total } & 5125.111 & 81 & & & \\
\hline
\end{tabular}


Tabel. 11 Hasil Uji Linearitas $\mathrm{Y} * \mathbf{X 3}$

Tabel. 10

ANOVA Table

\begin{tabular}{|c|c|c|c|c|c|c|c|}
\hline & & & $\begin{array}{l}\text { Sum of } \\
\text { Squares }\end{array}$ & Df & $\begin{array}{c}\text { Mean } \\
\text { Square }\end{array}$ & $\mathrm{F}$ & Sig. \\
\hline \multirow[t]{5}{*}{$\mathrm{Y} * \mathrm{X} 3$} & Between & (Combined) & 5092.801 & 44 & 115.745 & 132.545 & .000 \\
\hline & Groups & Linearity & 1788.028 & 1 & 1788.028 & 2047.540 & .000 \\
\hline & & Deviation from Linearity & 3304.773 & 43 & 76.855 & 88.010 & .000 \\
\hline & \multicolumn{2}{|c|}{ Within Groups } & 32.310 & 37 & .873 & & \\
\hline & \multicolumn{2}{|l|}{ Total } & 5125.111 & 81 & & & \\
\hline
\end{tabular}

Tabel 12. Hasil Uji Linearitas $Y * X 4$

ANOVA Table

\begin{tabular}{|c|c|c|c|c|c|c|c|}
\hline & & & $\begin{array}{l}\text { Sum of } \\
\text { Squares }\end{array}$ & Df & $\begin{array}{l}\text { Mean } \\
\text { Square }\end{array}$ & $\mathrm{F}$ & Sig. \\
\hline \multirow[t]{5}{*}{$\mathrm{Y} * \mathrm{X} 4$} & Between & (Combined) & 4332.122 & 41 & 105.662 & 5.330 & .000 \\
\hline & Groups & Linearity & 1537.147 & 1 & 1537.147 & 77.537 & .000 \\
\hline & & Deviation from Linearity & 2794.974 & 40 & 69.874 & 3.525 & .000 \\
\hline & \multicolumn{2}{|c|}{ Within Groups } & 792.989 & 40 & 19.825 & & \\
\hline & \multicolumn{2}{|l|}{ Total } & 5125.111 & 81 & & & \\
\hline
\end{tabular}

Pengaruh Materi Diklat Terhadap Partisipasi Anggota

Pengaruh materi diklat terhadap partisipasi anggota terbukti positif dan signifikan. Hal ini dibuktikan dengan nilai $\mathrm{t}_{\text {hitung }} 8.462>\mathrm{t}$ tabel 1.296 . dengan hasil signifikansinya sebesar 0.000 , sehingga Ha diterima. Besarnya pengaruh materi diklat terhadap partisipasi anggota terhadap tingkat partisipasi anggota sebagai pemilik dan pelanggan ditunjukan dari angka korelasi (r) sebesar 0.687. Menurut pendapat Guilford, jika koefisien korelasi berada dalam kisaran (range) $( \pm 0.4 \leq \mathrm{r}< \pm 0.7)$ berarti hubungan antara materi dengan partisipasi anggota cukup erat. Sedangkan besarnya nilai koefisien determinasi ( $R$-square) adalah 0.472 yang menunjukan tingkat pengaruh materi diklat terhadap partisipasi anggota.

Tabel 13. Uji Hipotesis Pengaruh Materi Terhadap Partisipasi Anggota

Coefficients $^{\mathrm{a}}$

\begin{tabular}{|c|c|c|c|c|c|}
\hline \multirow[b]{2}{*}{ Model } & $\begin{array}{r}\text { Unst } \\
\mathrm{Co} \\
\end{array}$ & $\begin{array}{l}\text { idardized } \\
\text { ficients }\end{array}$ & $\begin{array}{l}\text { Standardized } \\
\text { Coefficients }\end{array}$ & \multirow[b]{2}{*}{$\mathrm{T}$} & \multirow[b]{2}{*}{ Sig. } \\
\hline & B & Std. Error & Beta & & \\
\hline (Constant) & 10.811 & 4.373 & & 2.472 & .016 \\
\hline $\mathrm{X} 1$ & .496 & .059 & 687 & 8.462 & .000 \\
\hline
\end{tabular}

a. Dependent Variable: $Y$

Tabel 14. Uji Pengaruh Materi Diklat Terhadap Partisipasi Anggota

Model Summary ${ }^{\mathrm{b}}$

$\begin{array}{ccccc}\text { Model } & \text { R } & \text { R Square } & \begin{array}{c}\text { Adjusted R } \\ \text { Square }\end{array} & \begin{array}{c}\text { Std. Error of } \\ \text { the Estimate }\end{array} \\ 1 & .687^{\mathrm{a}} & .472 & .466 & 5.81384\end{array}$

a. Predictors: (Constant), $X 1$

b. Dependent Variable: $Y$ 
Untuk mengetahui pengaruhnya, berikut disampaikan hasilnya :

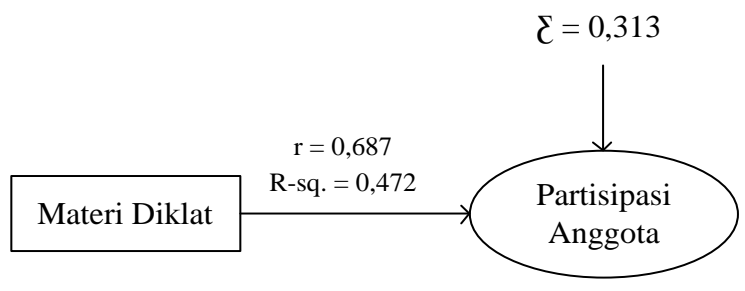

Gambar 4

Pengaruh Materi Diklat Terhadap Partisipasi Anggota

Tabel 15. Rangkuman Uji Hipotesis Materi Terhadap Partisipasi Anggota

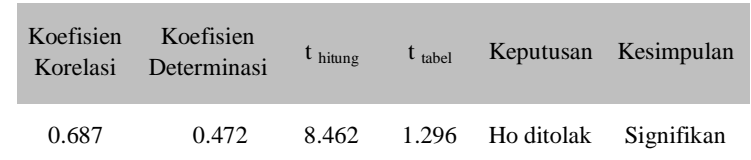

Pengaruh Metode dan Media Diklat Terhadap Partisipasi Anggota

Hasil pengujian hipotesis tentang pengaruh metode dan media terhadap partisipasi anggota, diperoleh hasil perhitungan nilai $\mathrm{t}$ hitung 7.018, dan nilai $\mathrm{t}$ tabel 1.296 , maka dengan membandingkan $\mathrm{t}$ hitung dengan $\mathrm{t}$ tabel tersebut disimpulkan menolak Ho dan menerima Ha, dengan demikian maka terbukti ada pengaruh positif dan signifikan antara metode dan media terhadap partisipasi anggota, sebagaimana data berikut ini :

Tabel 16 Uji Hipotesis Pengaruh Metode dan Media Terhadap Partisipasi Anggota

Coefficients $^{\mathrm{a}}$

\begin{tabular}{lccccccc}
\hline & & Unstandardized & Coefficients & Standardized & coefficients & & \\
\cline { 3 - 6 } Model & & $\mathrm{B}$ & Std. Error & Beta & $\mathrm{t}$ & Sig. \\
\hline \multirow{2}{*}{1} & (Constant) & 18.166 & 4.226 & & & 4.298 & .000 \\
\cline { 2 - 7 } & $\mathrm{X} 2$ & .709 & .101 & .617 & 7.018 & 000 \\
\hline
\end{tabular}

a. Dependent Variable: $Y$

\section{Tabel 17 Uji Pengaruh Metode dan Media Terhadap Partisipasi Anggota}

$\begin{array}{ccccc}\text { Model } & \mathrm{R} & \mathrm{R} \text { Square } & \begin{array}{c}\text { Adjusted R } \\ \text { Square }\end{array} & \begin{array}{c}\text { Std. Error of the } \\ \text { Estimate }\end{array} \\ 1 & .617^{\mathrm{a}} & .381 & .373 & 6.29683\end{array}$

a. Predictors: (Constant), $X 2$

b. Dependent Variable: $Y$

Besarnya pengaruh metode dan media terhadap partisipasi anggota dapat digambarkan sebagai berikut :

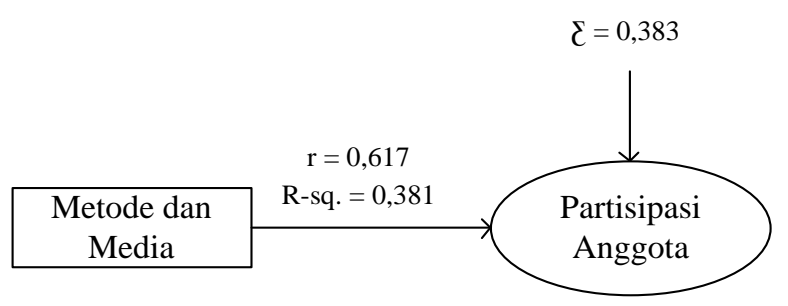

\section{Gambar 5. Pengaruh Metode dan Media terhadap Partisipasi Anggota}

Berdasarkan data di atas, diketahui nilai koefisien korelasi (r) 0.617, dimana setiap adanya peningkatan metode dan media sebesar satu satuan, maka partisipasi anggota juga meningkat 0.617 atau $61.7 \%$. Sedangkan besar pengaruhnya ( $R$-square) adalah 0.381 atau $38.1 \%$. Metode dan media digunakan untuk menyampaikan materi agar dapat dipahami dan memiliki dampak terhadap tingkat patisipasi anggota dalam berkoperasi. Metode yang efektif memudahkan peserta memahami materi diklat dan penggunaan media yang tepat sebagai upaya bagian dari penggunaan metode yang digunakan saat diklat. Penggunaan media, berupa penggunaan alat peraga atau melibatkan benda-benda menurut pendapat Made Pidarta (2007:5) adalah merupakan teori mendidik didaktik atau dikenal dengan istilah Proses Belajar Mengajar (PBM). Dari hasil penelitian diketahui hasil jawaban responden mendapat skor $71 \%$, sehingga dapat disimpulkan bahwa responden setuju dengan metode yang diterapkan dan penggunaan media tersebut dalam pendidikan anggota.

Pengaruh Pelatih Diklat Terhadap Partisipasi Anggota 
Hasil pengujian hipotesis, diketahui pengaruh dari pelatih diklat terhadap partisipasi anggota diketahui nilai $\mathrm{t}_{\text {-hitung }} 6.551>\mathrm{t}_{\text {-tabel }} 1.296$, maka Ho ditolak dan
Ha diterima. Dengan demikian diketahui bahwa terdapat pengaruh yang positif dan signifikan pelatih terhadap partisipasi anggota.

Tabel 18. Uji Hipotesis Pengaruh Pelatih Diklat Terhadap Partisipasi Anggota

\begin{tabular}{|c|c|c|c|c|c|c|}
\hline & & & Coefficient & & & \\
\hline & \multirow[t]{2}{*}{ Model } & \multicolumn{2}{|c|}{ Unstandardized Coefficients } & $\begin{array}{l}\text { Standardized } \\
\text { Coefficients }\end{array}$ & \multirow[t]{2}{*}{$\mathrm{t}$} & \multirow[t]{2}{*}{ Sig. } \\
\hline & & B & Std. Error & Beta & & \\
\hline \multirow[t]{2}{*}{1} & (Constant) & 17.165 & 4.673 & & 3.673 & .000 \\
\hline & X3 & .995 & .152 & .591 & 6.551 & .000 \\
\hline
\end{tabular}

Tabel 19 Uji Pengaruh Pelatih Diklat Terhadap Partisipasi Anggota Model Summary ${ }^{\mathrm{b}}$

$\begin{array}{lcccc}\text { Model } & \mathrm{R} & \mathrm{R} \text { Square } & \text { Adjusted R Square } & \text { Std. Error of the Estimate } \\ 1 & .591^{\mathrm{a}} & .349 & .341 & 6.45710 \\ \text { a. Predictors: (Constant), } X 3 & & & \\ \text { b. Dependent Variable: } Y & & & & \end{array}$

Untuk mengetahui besarnya pengaruh pelatih diklat terhadap partisipasi anggota, dapat di gambarkan sebagaimana berikut ini :

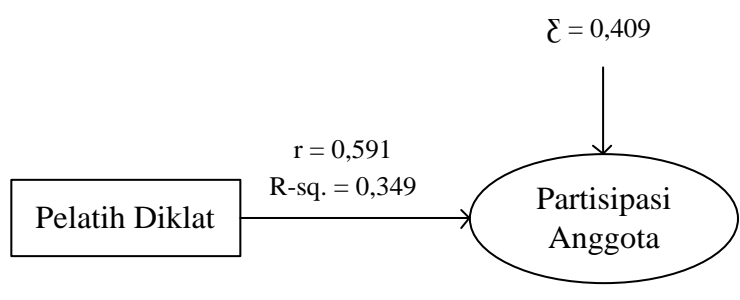

\section{Gambar 6. Pengaruh Pelatih Diklat Terhadap Partisipasi Anggota}

Dengan demikian terbukti bahwa unsur pelatih memiliki pengaruh positif terhadap partisipasi anggota. Hal tersebut dapat dilihat dari nilai koefisien korelasi (r) dari variabel pelatih terhadap variabel partisipasi anggota adalah sebesar 0.591 atau $59.1 \%$, mengandung arti bahwa setiap adanya peningkatan kompetensi pelatih sebesar satu satuan, maka partisipasi anggota dapat ditingkatkan sebesar 0.591 atau $59.1 \%$. Sedangkan besar pengaruhnya (R-square) adalah 0.349 atau $34.9 \%$.

\section{Pengaruh Peserta Diklat Terhadap Partisipasi Anggota}

Hasil pengujian hipotesis pengaruh peserta diklat terhadap partisipasi aggota, diperoleh nilai $\mathrm{t}$ hitung $5.854>$. Adapun $t$ tabel pada taraf signifikasi $10 \%$ dengan derajat kebebasan (df) 81 adalah 1.296, Maka Ho ditolak dan Ha diterima. Artinya terdapat pengaruh positif dan signifikan antara pelatih terhadap partisipasi anggota karena $\mathrm{t}_{\text {-hitung }} 5.854>$ $\mathrm{t}_{\text {-tabel }}$ 1.296. Dan hasil signifikansinya sebesar 0.000 sehingga Ha diterima karena $\mathrm{p}<\alpha$.

Tabel 20. Uji Hipotesis Pengaruh Peserta Diklat Terhadap Partisipasi Anggota

Coefficients $^{\mathrm{a}}$

\begin{tabular}{|c|c|c|c|c|c|c|}
\hline \multirow{2}{*}{\multicolumn{2}{|c|}{ Model }} & \multicolumn{2}{|c|}{ Unstandardized Coefficients } & \multirow{2}{*}{$\begin{array}{c}\text { Standardized } \\
\text { Coefficients } \\
\text { Beta }\end{array}$} & \multirow[t]{2}{*}{$\mathrm{T}$} & \multirow[t]{2}{*}{ Sig. } \\
\hline & & B & Std. Error & & & \\
\hline \multirow[t]{2}{*}{1} & (Constant) & 24.398 & 4.002 & & 6.097 & .000 \\
\hline & $\mathrm{X} 4$ & .878 & .150 & .548 & 5.854 & .000 \\
\hline
\end{tabular}

a. Dependent Variable: $Y$ 
Tabel 21. Uji Pengaruh Peserta Terhadap Partisipasi Anggota Model Summary ${ }^{\mathrm{b}}$

$\begin{array}{ccccc}\text { Model } & \mathrm{R} & \mathrm{R} \text { Square } & \text { Adjusted R Square } & \text { Std. Error of the Estimate } \\ 1 & .548^{\mathrm{a}} & .300 & .291 & 6.69697\end{array}$

a. Predictors: (Constant), X4

b. Dependent Variable: $Y$

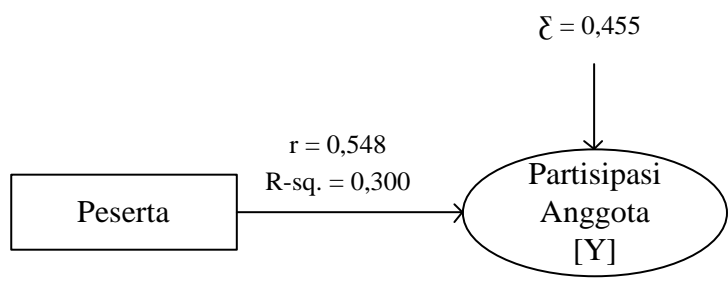

Gambar 7. Pengaruh Peserta Diklat Terhadap Partisipasi Anggota

Besarnya pengaruh peserta diklat terhadap partisipasi anggota terlihat dari koefisien korelasi (r) 0.548 atau $54.8 \%$. Sedangkan besar pengaruhnya (R-square) $\quad 0.300$ atau $30 \%$. Peserta sebagai pelaku dalam kegiatan pendidikan dan pelatihan diperlakukan sebagai warga belajar dan bukan objek belajar, sehingga peserta dan pendidik terjadi komunikasi yang interaktif.

Pengaruh Materi Diklat, Metode dan Media, Pelatih, Peserta Diklat Terhadap Partisipasi Anggota Secara Simultan
Berdasarkan hasil penelitian dapatlah diketahui bahwa materi diklat, metode dan media, pelatih, peserta memiliki pengaruh yang positif terhadap partisipasi anggota sebagai pemilik dan pelanggan. Hal tersebut dapat diketahui dari nilai koefisien korelasi (r) variabel materi diklat, metode dan media, pelatih, peserta terhadap partisipasi anggota yaitu 0.745, yang bermakna bahwa setiap peningkatan satu satuan variabel materi diklat, metode dan media, pelatih, peserta akan berpengaruh terhadap partisipasi anggota sebagai pemilik dan pelanggan 0.745 atau $74.5 \%$. Sedangkan besarnya pengaruh $R$-Square 0.556, yang mencerminkan bahwa materi diklat, metode dan media, pelatih, peserta secara simultan berpengaruh terhadap partisipasi anggota sebagai pemilik dan pelanggan $55.6 \%$. Hasil uji hipotesis pengaruh materi diklat, metode dan media, pelatih dan peserta terhadap partisipasi anggota disajikan berikut ini :

Tabel 22. Hasil Uji Hipotesis Pengaruh Materi, Metode dan Media, Pelatih, Peserta Diklat Terhadap Partisipasi Anggota sebagai pemilik dan pelanggan

\begin{tabular}{llccccc}
\multicolumn{7}{c}{ ANOVA $^{\mathrm{a}}$} \\
\hline Model & & Sum of Squares & df & Mean Square & F & Sig. \\
\hline 1 & Regression & 2847.699 & 4 & 711.925 & 24.075 & $.000^{\mathrm{b}}$ \\
& Residual & 2276.956 & 77 & 29.571 & & \\
& Total & 5124.656 & 81 & & & \\
\hline
\end{tabular}

a. Dependent Variable: $Y$

b. Predictors: (Constant), X4, X3, X2, X1

Tabel 23. Pengaruh Materi, Metode dan Media, Pelatih, Peserta Diklat Terhadap Partisipasi Anggota sebagai pemilik dan pelanggan

Model Summary ${ }^{\mathrm{b}}$

$\begin{array}{ccccc}\text { Model } & \mathrm{R} & \mathrm{R} \text { Square } & \text { Adjusted R Square } & \text { Std. Error of the Estimate } \\ 1 & .745^{\mathrm{a}} & .556 & .533 & 5.43791\end{array}$

a. Predictors: (Constant), X4, X3, X2, X1

b. Dependent Variable: $Y$ 


\section{KESIMPULAN DAN SARAN}

\section{Kesimpulan}

1) Secara parsial terbukti bahwa faktor pendidikan dan pelatihan anggota yang terdiri dari materi diklat, metode dan media, pelatih, peserta memiliki hubungan dan pengaruh positif dan signifikan terhadap partisipasi anggota sebagai pemilik dan pelanggan. Semakin baik materi diklat yang diajarkan, semakin efektif metode dan media yang digunakan, semakin baik kompetensi yang dimiliki pelatih dan semakin aktif peserta terlibat dalam proses belajar mengajar, maka semakin paham anggota akan hak dan kewajibannya serta manfaat berkoperasi, maka semakin tinggi tingkat partisipasi anggota sebagai pemilik dan pelanggan.

2) Secara simultan terbukti bahwa faktor pendidikan dan pelatihan anggota memiliki hubungan dan pengaruh positif dan signifikan terhadap partisipasi anggota sebagai pemilik dan pelanggan. Semakin faktor-faktor pendidikan dan pelatihan anggota tersebut dapat lebih efektif dan kualitasnya lebih ditingkatkan lagi, maka semakin paham anggota akan hak dan kewajibannya serta lebih dapat merasakan manfaat (benefit) berkoperasi, maka semakin tinggi tingkat partisipasi anggota sebagai pemilik dan sekaligus sebagai pelanggan.

3) Materi diklat terbukti lebih dominan pengaruhnya dibandingkan metode dan media, pelatih maupun peserta diklat. Dengan demikian maka efektivitas materi diklat turut dipengaruhi oleh metode dan media yang digunakan, kualitas dan kompetensi pelatih serta peran aktif dari peserta diklat selama proses belajar mengajar berlangsung.

4) Partisipasi anggota sebagai pemilik dan sebagai pelanggan pada Koperasi Kojamas terbukti positif karena adanya pemahaman dan kesadaran anggota yang timbul setelah mendapatkan pendidikan dan pelatihan anggota.

\section{Saran}

1) Pendidikan dan pelatihan anggota sangat penting diberikan kepada setiap anggota koperasi untuk meningkatkan pengetahuan, kemampuan, sikap dan menimbulkan kesadaran berpartisipasi, termasuk peningkatan kompetensi bagi pengurus dan pengelola koperasi.

2) Partisipasi anggota timbul melalui tahapan AISAS (awareness/attention, interest, search, action, share). Sehingga model diklat anggota perlu diselaraskan dengan tahapan tersebut agar efektif untuk meningkatkan pemahaman anggota tentang perkoperasian, kesadaran terhadap hak dan kewajiban anggota dan kesadaran berpartisipasi.

\section{DAFTAR PUSTAKA}

Hanel, Alfred. (2005). Organisasi Koperasi. Edisi pertama. Yogyakarta: Graha Ilmu.

Herman Soewardi. (1989). Koperasi (Suatu Kumpulan Makalah). Jatinangor: UPT. Penerbitan Ikopin.

H. Fuad Ihsan. (2010). Dasar-Dasar Kependidikan Komponen MKDK. Jakarta: Rineka Cipta.

H. Rusidi, Maman Suratman (editor). (2002). 20 Bunga Rampai Pokok Pemikiran Tentang Pembangunan Koperasi. Jatinangor:Ikopin.

H. A. Rusdiana. (2014). Manajemen Operasi. Bandung: CV Pustaka Setia.

Ibnoe Soedjono. (2013). Jatidiri Koperasi. Jakarta: LSP2I.

Made Pidarta. (2007). Landasan Kependidikan. Edisi II. Jakarta: Rineka Cipta.

Malayu S. P. Hasibuan. (2014). Manajemen Sumberdaya Manusia, Ed. Revisi. Jakarta: Bumi Aksara.

Panji Anoraga dan Ninik Widiyanti. (1993). Dinamika Koperasi. Jakarta: Rineka Cipta.

Ramudi Ariffin. (2013). Koperasi Sebagai Perusahaan. Cetakan pertama. Jatinangor: Ikopin.

Rully Indrawan. (2004). Ekonomi Koperasi Ideologi, Teori dan Praktik Berkoperasi. Bandung: Lemlit Universitas Pasundan.

Röpke, Jochen. (2000). Ekonomi Koperasi Teori dan Praktik. Jakarta: Salemba Empat.

Syamsuddin Mahmud. (1986) Dasar-Dasar Ilmu Ekonomi dan Koperasi. Edisi ke-2. Banda Aceh: PT Intermasa.

Thoby Mutis. (2004). Pengembangan Koperasi Kumpulan Karangan. Cetakan Keempat. Jakarta: PT Gramedia Widiasarana.

Umar Tirtarahardja dan S.L.La Sulo. (2013). Pengantar Pendidikan. Edisi Revisi. Jakarta: PT Rineka Cipta 